\title{
"Still covered in sand.looked very old."-Legal Obligations in the Internet Market for Antiquities
}

\author{
Lauren Dundler(i) \\ Department of Ancient History, Macquarie University, Sydney 2109, Australia; lauren.dundler@hdr.mq.edu.au \\ Received: 5 July 2019; Accepted: 30 July 2019; Published: 6 August 2019 \\ check for \\ updates
}

\begin{abstract}
The global internet antiquities market exists in a complex cultural heritage framework, comprised of international law and domestic legislation. In this paper, the questions I seek to answer are the following: how do internet antiquities dealers engage with their legal obligations, and how is this engagement translated to the ethics of their businesses? This paper presents a comparative examination of 45 antiquities dealers split across three categories-internet dealers, eBay dealers and social media dealers-revealing three key insights about the internet antiquities market: firstly, that the level of legal literacy in the market is depicted as being quite poor; secondly, that the performance of legal awareness does not always correspond with ethical dealer practices; and finally, some dealers utilise a suite of justifications for their behaviours, practices and values (known as neutralisation techniques) to undermine their legal obligations. Such results confirm existing claims of the failure of self-regulation in the internet antiquities market and reveal a demand for educational campaigns targeted at raising consumer awareness by challenging misleading market narratives and highlighting the ethical and legal issues involved with the trade of cultural heritage.
\end{abstract}

Keywords: internet antiquities market; neutralisation techniques; legal literacy

\section{Introduction}

In July 2018, a cuneiform tablet was sold for $\$ 99$ on the auction-hosting platform, eBay [1]. The seller was based in Netanya, Israel, and had been active on eBay since March 2017. What immediately stood out was the lot description, including the phrase: "I do not know if it's real or not. Looks authentic-Without documents." In comparison with the standard hyperbolic claims of eBay antiquities sellers, this eBay user's statement was unique. Absent are the promises of authenticity, the appeals to expertise or any attempts to provide verifiable provenance. Further, the dealer provided the following item description for the tablet: "Still covered in sand.looked very old [sic]. You can see in the pictures." Whilst the dealer offered the vague provenance of a London-based acquisition, accompanied with the testimony that all their items come "from a legal source", the legality of this sale is questionable.

Since the Gulf War, political instability and ongoing conflict has created ideal conditions for widespread antiquities looting and smuggling in Iraq, resulting in the market for cuneiform objects increasing in volume at such a rapid size and rate that it could only be attributed to the introduction of recently looted material. In an investigation into the state of the antiquities market between 1990 and 2003, Neil Brodie concluded that this "new material could only have been moving out of Iraq through illegal means" [2] (p. 119). An example of looting and trafficking in this context can be seen in the case of Hobby Lobby. The corporation has been the subject of federal investigation since 2011 when their shipment of approximately 3000 clay bullae and 450 cuneiform tablets was seized by United States (US) Customs agents in Memphis, Tennessee, whilst on route to Oklahoma City from Israel [3]. These tablets, similar to the other 40,000 or so antiquities owned by Hobby Lobby, were intended for the 
Museum of the Bible, a giant new museum, which was funded by the Greens family and opened in Washington, D.C., in November 2017 [4,5].

The illicit trade of cultural heritage is not a modern issue. Nor is it one that has evaded scholarly attention. For a long time now, we have been made aware of the legal, ethical and socio-political impacts stemming from the unlawful, or morally dubious, collection of objects of cultural significance-especially when these objects have originated from colonial contexts and conflict zones. Further, the relationship between antiquities crime and organised crime, including money laundering and terrorist financing, has been illustrated in a number of studies [6-9]. For the past two decades, market participants have transitioned to e-commerce, taking advantage of both auction- and sales-hosting websites, such as eBay, Invaluable, Etsy and Live Auctioneers, as well as using their own websites to buy and sell antiquities [10-16]. More recently, antiquities sales have been found to occur beyond traditional online marketplaces on social media platforms, including Facebook and Instagram [17].

In 2006, the United Nations Educational, Scientific and Cultural Organization (UNESCO), the International Council of Museums (ICOM), and the International Criminal Police Organization (INTERPOL) jointly published a set of preliminary guidelines in response to the burgeoning internet market for antiquities [18]. Their recommendations are preceded by an acknowledgement of the "ongoing increase" of illicit trafficking of cultural objects facilitated by the internet. To counter these concerns, they invite member states and states with ICOM National Committees, inter alia, to strongly encourage internet sales platforms to post this disclaimer on all their cultural objects sales pages:

With regard to cultural objects proposed for sale, and before buying them, buyers are advised to: (i) check and request a verification of the licit provenance of the object including documents providing evidence of legal export (and possibly import) of the object likely to have been imported; (ii) request evidence of the seller's legal title. In case of doubt, check primarily with the national authorities of the country of origin and INTERPOL, and possibly with UNESCO or ICOM.

Over a decade since the publication of these recommendations, the specific language of this disclaimer is nowhere to be seen in the businesses of internet dealers. This fact is highlighted by Neil Brodie in his policy brief for the Antiquities Coalition [19] and is also supported by my own observations of the internet antiquities market. In his policy brief, Brodie is particularly concerned by the lack of self-regulation evident in the businesses of internet dealers, with a failure not only to enforce existing rules but to even present them to potential customers in the first place [19] (p. 10).

\section{Materials and Methods}

The antiquities market exists within a complex legal framework: domestic and international jurisdiction; soft and hard law; and contemporary and historical crimes. For those operating in the market, cooperation and compliance with these laws and regulations are crucial to ensuring ethical conduct that does not support the illicit trade of antiquities. However, what do these obligations look like in reality? The questions that I seek to address in this paper are the following: How evident are legal obligations in the internet market for antiquities? How do internet dealers communicate their engagement with the complex international legal framework to their buyers? How does legal understanding, or lack thereof, translate to the standards of provenance in the internet antiquities market? Using data from the internet antiquities sales of 45 online dealers, in this paper, I will explore the relationship between legal awareness and ethical practice. The dealers come from three different categories of the internet market: dealers who operate primarily through their own websites; dealers who use the auction-hosting website eBay; and the recently emerging group of social media dealers.

This study is based off of four related hypotheses: firstly, internet dealers will have a higher engagement with the legal framework due to the likelihood that their businesses are more established, therefore accounting for greater experience with the market; secondly, eBay dealers will have the most 
diverse level of engagement compared with the other two groups of dealers, as both experienced and amateur dealers use eBay as a selling platform; thirdly, the lowest level of engagement will occur in the businesses of amateur dealers, most commonly manifested on eBay and social media platforms; and finally, a high engagement with the legal framework should correspond with antiquities sold with verifiable provenance. Low engagement should, therefore, be associated with poorly provenanced antiquities.

The data for this paper was collated over a six-month period, starting in late 2018. The dealers were identified using keyword searches that potential buyers of antiquities would use, e.g., "antiquities for sale", "artefacts for sale" and "genuine artefacts". A random sample of 15 dealers for each category was then selected based on their position on the search engine results page, being the first 15 dealers identified who claimed to be selling genuine antiquities or artefacts. Dealers selling objects they identified as replicas were excluded from the selection process. The only exception to this process was the inclusion of the aforementioned Israel-based eBay user, who was included due to prior knowledge of their operations. Given the vast number of sellers on the internet dealing in antiquities, it is worth noting that examining only 45 dealers is a limitation of this study. However, the aim of this study is not to record the legal engagement of the internet market of antiquities in its entirety but, rather, to identify common trends and practices of dealers across the different categories.

As expected, the dealers were primarily from the United States, the United Kingdom, and Europe. A few outliers were the Australian social media dealers, who were identified in the Facebook Marketplace-a selling forum that searches your immediate area unless you change your select location manually, which was done to identify dealers in the most traditionally important centres of trade for the antiquities market: London and New York. The dealers were separated into their categories based on how they were located in the online marketplace. Naturally, there is crossover between the categories, as some dealers use multiple selling platforms, and this will be demonstrated in the results. Apart from the location and the types of selling platforms they utilise, the dealers are presented anonymously in the results of this study. Whilst maintaining the anonymity of subjects is a "standard, widely accepted criminological method" [20] (p. 210), it is necessary to acknowledge the ethical concerns inherent with reproducing names associated with online identities. Online social networks have long been recognised as vulnerable to identity theft, and this issue is further compounded by the rise in fake social media profiles, which often involve the creation of an online presence based on a real, nonconsenting person's identity [21]. It is necessary, then, when extracting research data from social media, and the internet more broadly, to protect identifying features of subjects (names, photos and other unique biographical information), and it is for these reasons that the dealers are de-identified in this study.

Internet dealers operate through their own, independent websites. They are dealers who have been in business for more than a decade and may also have traditional brick-and-mortar businesses. Sometimes they use eBay and social media to broaden their business prospects. They are also more likely to disclose personal information, including their full names, and testimonies to their market experience and expertise.

The second category of dealers comprises users of the auction- and sales-hosting platform eBay. Their experience and expertise are the most varied, with some dealers in operation since 2002 and others appearing as recently as 2017. Whilst some may have websites or social media profiles external to eBay to support their business, the majority restrict their operations to this selling platform and offer little information about their credentials or even identity. As users of eBay, they have to abide by the site's terms and agreements, which does include policies on the trade of cultural heritage. However, the exact wording and, indeed, the visibility of these policies vary from country to country. For example, German eBay offers an explicit definition of an antiquity and requires any antiquities offered for sale to be accompanied with valid documentation of legal export from the country of origin. The United States, on the other hand, identifies an antiquity as an item of "cultural significance", which is ideally presented for sale with an image of the necessary documentation. In his policy brief for 
the Antiquities Coalition, Brodie acknowledges these written rules as "broadly in line with the 2006 ICOM/INTERPOL/UNESCO recommendations" [19] (p. 10).

The final group of dealers represents the growing trend of antiquities sales facilitated by social media, including Facebook and Instagram. Most of the dealers in this group only offer a few antiquities for sale at a given time compared with the other two types of dealers who may have as many as thousands of antiquities on offer. There are also key differences between Facebook and Instagram that must be acknowledged. Facebook is an American social networking platform that operates worldwide, with the exclusion of blocking countries. One of the services it provides to its 2.3 billion users is a buying and selling platform, known as the Facebook Marketplace, which enables e-commerce exchange. Antiquities sales do occur on the Marketplace, but there is ongoing research that demonstrates how illicit commerce takes place on Facebook via groups—public, closed or secret—with prices and locations of wares included on posts or discussed by market participants via direct messages [17]. Instagram is a photo- and video-sharing social networking service, which is owned by Facebook, Inc. It does not have a designated buying and selling platform similar to the Facebook Marketplace. Instead, sales of antiquities involve a dealer posting images of available wares with a request for a direct message or a link to a supplementary sales page, usually hosted on eBay or the dealer's own website. As is the case with eBay dealers, social media dealers are also obligated to follow the site's terms and agreements, which dictate what can and cannot be sold. Currently, in Facebook's commerce policies, which cover both the Facebook Marketplace and Instagram activity, there are no specific restrictions concerning the trade of cultural heritage as there are for the buying and selling of narcotics, alcohol, firearms and animals. There are, however, stipulations in their community standards, which prohibit the platform from being used to support criminal activity. Both eBay and Facebook utilise a user-reporting function to ensure that their commerce policies are followed.

In order to test the four hypotheses, the following criteria were considered when analysing the three groups of internet dealers: the first being legal awareness and the second being the quality of provenance. In the context of this study, legal awareness is identifiable through an engagement, or lack thereof, with the cultural heritage legal framework. It is an expression of legal literacy and thus exists on a continuum from legally trained actors, such as lawyers and judges, to non-legally trained actors. This understanding of legal awareness comes from the work of legal scholar James Boyd White, who framed legal literacy as "that degree of competence in legal discourse required for meaningful and active life in our increasingly legalistic and litigious culture" [22] (p. 144).

In the context of this study, a demonstration of legal awareness could include engagement with any part of the cultural heritage legal framework, consisting of international law-including two key conventions and bilateral agreements, also known as memoranda of understanding (MoUs) —and domestic exportation laws, which restrict the trade of antiquities. The two international conventions relevant to this study are the 1970 UNESCO Convention on the Means of Prohibiting and Preventing the Illicit Import, Export and Transfer of Ownership of Cultural Property and the 1995 International Institute for the Unification of Private Law (UNIDROIT) Convention on Stolen or Illegally Exported Cultural Objects. They are compatible and complementary documents, which provide an international framework for regulating the trade of cultural heritage, including preventative measures and restitution provisions and fostering international cooperation between the source and market countries [23-25]. These international agreements are then implemented at the domestic level through national legislation. When engaging in the market, antiquities collectors and dealers operate within this international legal framework; however, they are also subject to national exportation laws and bilateral agreements made between the source and market countries.

However, a demonstration of legal awareness can also be as rudimentary as the claim made by the seller of the cuneiform tablet: "All my items come from a legal source." Whilst this is not information that could be used to determine whether the operations of this eBay user abide by the relevant cultural heritage laws and regulations, it is still an indication of the dealer's awareness of their legal obligations in the context of this study. 
In terms of provenance, this was not a study that aimed to identify every time a dealer did or did not engage with provenance but, rather, an attempt to encapsulate the types of provenance narratives used. Provenance is a market mechanism that directly engages with the ethics of antiquities acquisitions as it acts as both a testimony to the origins of an object as well as a record of prior ownership history. When examining the dataset, the quality of provenance narratives was considered on a scale of high to low quality. Antiquities that offered high-quality provenance were presented by the dealers with information that could serve as legal testimony for the object in a contemporary legal context. Such information includes an object's provenience- "the physical location of an artifact in four-dimensional space", which is "empirical and absolute" [26] (p. 212)—or records of a legal export from the source country to its destination. On the other end of the spectrum, low-quality provenance was regarded as incomplete or insufficient provenance information. This could include a complete lack of provenance, which is common, or the use of industry clichés, such as "the property of the gentleman" or "found in the family attic". Average-quality provenance encompassed the types of provenance that fall in between these two extremes: details of ownership history that omit provenience and instead focus on the experience and expertise of the collectors and dealers who have handled the object.

\section{Results}

\subsection{Internet Dealers}

Of the 15 internet dealers, 12 demonstrated legal awareness by engaging with international cultural heritage conventions and domestic antiquities exportation laws. In terms of provenance quality, there were nine examples of average-quality statements-mainly ownership narratives that could not serve as legal testimony-and the remaining five dealers communicated high-quality provenance. Of the latter category, multiple examples of provenience were disclosed; however, they were of varying levels of detail. The majority of internet dealers used multiple selling platforms, including eBay, social media profiles, and brick-and-mortar businesses, with only three exclusions: ID.13, 14 and 15 (Table 1).

A closer examination of these results reveals some common trends in legal engagement and provenance quality. The 1970 UNESCO Convention, for example, was referenced by five of the 15 internet dealers. A Colorado-based dealer (ID.2, Table 1) cited the treaty as part of their "How to Buy" guidelines. Two London-based antiquities sellers did the same in their frequently asked questions section (FAQs), using the treaty and other antiquities laws to frame their understanding of legality in the antiquities trade. A Florida-based dealer (ID.12, Table 1), on the other hand, referred to the 1970 UNESCO Convention to explain how their collection came to be: "He [the dealer] lived in Japan, Italy and then Turkey in the mid-sixties; antiquities were abundant and legal to export. After UNESCO passed the Cultural Properties law, it was no longer possible to export from Turkey so a huge source of genuine antiquities dried up."

The final dealer in this group demonstrated by far the most comprehensive understanding of their legal obligations. A New Jersey-based dealer (ID.14, Table 1), who has been dealing antiquities since 1984, offered the highest engagement compared with any other dealer in this study. Not only did they refer to the 1970 UNESCO Convention, with specific framing for the US market, they also referenced the 1995 UNIDROIT Convention and a list of all cultural heritage bilateral agreements between the US and various source countries dating to August 2017. Further, the dealer recommended consulting a qualified attorney for specific legal advice when engaging with the antiquities market. Interestingly, despite this comprehensive and, indeed, impressive engagement with the international legal framework, the dealer's business did not reflect this awareness in the provenance of its sales. The majority of which were ownership history narratives, with only two specific lots offering verifiable provenance in the form of US Customs documents. 
Table 1. Results of Analysis of Legal Awareness and Provenance Quality in Internet Antiquities Dealers.

\begin{tabular}{|c|c|c|c|c|}
\hline Dealer No. & Location & Other Selling Platforms? & Legal Awareness Demonstrated? & Provenance Quality \\
\hline ID. $1^{1}$ & $\begin{array}{l}\text { New York, United States of } \\
\text { America (USA) and London, } \\
\text { United Kingdom (UK) }\end{array}$ & Brick-and-mortar business & Yes & $\begin{array}{c}\text { Average: } \\
\text { ownership history narratives. }\end{array}$ \\
\hline ID. 2 & Colorado, USA & Advertises via Facebook & $\begin{array}{l}\text { Yes } \\
\text { Reference to the United Nations Educational, Scientific and } \\
\text { Cultural Organization (UNESCO) } 1970 \text { Convention on the } \\
\text { Means of Prohibiting and Preventing the Illicit Import, } \\
\text { Export and Transport of Ownership of Cultural Property }\end{array}$ & $\begin{array}{l}\text { Average: } \\
\text { ownership history narratives. }\end{array}$ \\
\hline ID.3 & Washington, D.C., USA & $\begin{array}{l}\text { Brick-and-mortar business } \\
\text { Advertises via Twitter }\end{array}$ & $\begin{array}{l}\text { Yes } \\
\text { Policies include "due diligence" and "good faith" to the } \\
\text { "best of their ability". }\end{array}$ & $\begin{array}{c}\text { High } \\
\text { Provenience: Byzantine bronze diadem and bracelet gifted to } \\
\text { British Ambassador to Greece, Sir Francis Oswald Lindley. } \\
\text { High: }\end{array}$ \\
\hline ID. 4 & Montreal, Canada & $\begin{array}{l}\text { Advertises via Facebook } \\
\text { and Twitter }\end{array}$ & Yes & $\begin{array}{c}\text { French export licences provided with some lots; } \\
\text { Provenience: Egyptian steatite Taweret with collection label } \\
\text { on base inscribed "Donkey God of green marble excavated at } \\
\text { Memphis". }\end{array}$ \\
\hline ID.5 & Southampton, UK & Advertises via Facebook & $\begin{array}{l}\text { Yes } \\
\text { "We believe that the amount of looted material on the } \\
\text { market to be greatly exaggerated." }\end{array}$ & $\begin{array}{l}\text { High: } \\
\text { French export licences provided with some lots; } \\
\text { Provenience: UK-based metal detector finds. }\end{array}$ \\
\hline ID.6 & London, UK & $\begin{array}{l}\text { Brick-and-mortar business } \\
\text { Advertises via Instagram }\end{array}$ & No & $\begin{array}{c}\text { High: } \\
\text { Export licences from France, Spain and Israel; Provenience: } \\
\text { Shabti from the tomb of Iweferbaku, "emptied some time } \\
\text { before 1830s." }\end{array}$ \\
\hline ID.7 & London, UK & Used to sell on eBay & $\begin{array}{l}\text { Yes } \\
\text { Reference to } 1970 \text { UNESCO Convention; } \\
\text { "Illegal digging is almost exclusively done for artefacts at } \\
\text { the upper end of the market." }\end{array}$ & $\begin{array}{c}\text { Average: } \\
\text { ownership history narratives; } \\
\text { country of discovery e.g., "Found in X". }\end{array}$ \\
\hline ID. 8 & California, USA & $\begin{array}{l}\text { Live auctions via } \\
\text { Invaluable and Live } \\
\text { Auctioneers }\end{array}$ & $\begin{array}{c}\text { Yes } \\
\text { Reference to } 1970 \text { UNESCO Convention and other } \\
\text { "antiquities laws"; } \\
\text { does not purchase or export from "restricted countries". }\end{array}$ & $\begin{array}{c}\text { Average: } \\
\text { ownership history narratives; } \\
\text { country of discovery e.g., "Found in X" or "Found at ancient } \\
\text { battle site near X". }\end{array}$ \\
\hline ID. 9 & South Kensington, UK & $\begin{array}{l}\text { Live auctions via } \\
\text { Invaluable and Live } \\
\text { Auctioneers } \\
\text { Advertises via Instagram, } \\
\text { Facebook and Twitter }\end{array}$ & No & $\begin{array}{c}\text { High } \\
\text { Provenience: Faience Shabti “Originally from Deir el Bahri } \\
\text { cache II"; } \\
\text { ownership history including location, acquisition, collection } \\
\text { name; } \\
\text { withheld; “Property of a Gentleman”. }\end{array}$ \\
\hline ID.10 & California, USA & Used to sell on eBay & $\begin{array}{l}\text { Yes } \\
\text { Reference to The International Criminal Police Organization } \\
\text { (INTERPOL) Database of Iraq Museum looted materials. }\end{array}$ & $\begin{array}{l}\text { Average: } \\
\text { ownership history narratives; } \\
\text { significant representation of sales with no provenance data; } \\
\text { country of discovery e.g., "Found in X" or "Found at ancient } \\
\text { battle site near X". }\end{array}$ \\
\hline
\end{tabular}


Table 1. Cont

\begin{tabular}{|c|c|c|c|c|}
\hline Dealer No. & Location & Other Selling Platforms? & Legal Awareness Demonstrated? & Provenance Quality \\
\hline ID.11 & London, UK & $\begin{array}{l}\text { Advertises via Instagram, } \\
\text { Facebook and Twitter }\end{array}$ & $\begin{array}{l}\text { Yes } \\
\text { "We work with the police, cultural agencies and the } \\
\text { government to fight illicit trading of any kind." }\end{array}$ & $\begin{array}{c}\text { Average: } \\
\text { German export licences; } \\
\text { Military souvenirs. } \\
\text { Average: }\end{array}$ \\
\hline ID.12 & Florida, US and Savoie, France & Brick-and-mortar business & $\begin{array}{c}\text { Yes } \\
\text { Reference to } 1970 \text { UNESCO Convention. }\end{array}$ & $\begin{array}{c}\text { Ownership history narratives; } \\
\text { old European collections e.g., "Property of a European } \\
\text { Gentleman”. }\end{array}$ \\
\hline ID.13 & Grafton, Australia (AU) & Advertises on Facebook & No & $\begin{array}{c}\text { Average: } \\
\text { ownership history narratives; } \\
\text { significant representation of sales with no provenance data; } \\
\text { bronze bangle "thought to have been found in the Galilee } \\
\text { region." }\end{array}$ \\
\hline ID.14 & New Jersey, USA & No & $\begin{array}{c}\text { Yes } \\
\text { Detailed legal guidelines including reference to } 1970 \\
\text { UNESCO Convention, the International Institute for the } \\
\text { Unification of Private Law (UNIDROIT) 1995 Convention } \\
\text { on Stolen or Illegally Exported Cultural Objects and list of } \\
\text { US Memorandums of Understanding (MoUs) }\end{array}$ & $\begin{array}{c}\text { Average: } \\
\text { lot of } 42 \text { oil lamps and an Egyptian mummy mask crown } \\
\text { cleared by U.S. Customs; } \\
\text { ownership history narratives; } \\
\text { significant representation of sales with no provenance data. }\end{array}$ \\
\hline ID.15 & United Kingdom & No & $\begin{array}{l}\text { Yes } \\
\text { "I maintain a zero-tolerance approach to illicit, fake or } \\
\text { smuggled antiquities." }\end{array}$ & $\begin{array}{c}\text { Average: } \\
\text { ownership history narratives; } \\
\text { country of discovery e.g., "Found in X" or "Found at ancien } \\
\text { battle site near X". }\end{array}$ \\
\hline
\end{tabular}

collecting perspective. This example will be explored in more detail in Section 3.4. ${ }^{3}$. Again, this is a quote from the dealer's FAQ and will be explored further in Section 3.4. 
After references to the UNESCO Convention, the most common ways that these dealers engaged with the legal framework were via reference to export laws and restrictions. Again, these examples varied in their degrees of specificity but for the most part acknowledged how legality shifts across state borders in the global market. Being a London-based business, one dealer (ID.11, Table 1) highlighted that United Kingdom (UK) export of specific items can be restricted. A California-based dealer (ID.8, Table 1), on the other hand, used export laws as a framework for demarcating what antiquities they buy and sell.

\section{2. eBay Dealers}

Only three eBay dealers engaged with the legal framework. Further, the low levels of legal engagement corresponded with poor-quality provenance, represented in the provenance statements of eight dealers. Three of these dealers did not attempt to provide any provenance information to their sellers at all. Of the remaining dealers only one demonstrated high-quality provenance, with the rest identified as average quality. In regard to multiple selling platforms, only three dealers appeared to have a business presence beyond eBay. These dealers utilised social media platforms, such as Facebook, Instagram and Twitter, as advertising tools to further promote their eBay sales.

Of the three dealers who engaged with the legal framework, only one referred to a group of laws, namely export restrictions. The other two made generic testimonies to the legality of their businesses. The first eBay dealer (eD.1, Table 2) referred to UK export restrictions on almost all of their sales. They also attempted to support the legality of their business further by providing "authentic" provenance certificates. None of the information provided by this dealer could be considered verifiable provenance. This statement was consistent across the sales of these 15 eBay dealers with only two exclusions: a metal detector finds from Greece and a Cyprus limestone head with export documents from the Cypriot Government.

The second example of legal engagement in this group of dealers was generic testimonies of legality. The first we have looked at already, as it came from the Israel-based dealer (eD.12, Table 2). This eBay seller, despite making the claim that all their items came from a legal source, did nothing to demonstrate this through provenance narratives. Only a couple of sales included ownership history, being sourced from the seller's private collection after originally being purchased on eBay.

The second example from this category was from a US-based eBay seller (eD.13, Table 2) who claimed that their antiquities were of legal provenance and then supported this claim with an actual example of verifiable provenance. The lot in question was a Cypriot limestone head offered for $\$ 1000$ that had previously been owned by the Cyprus Museum of Jacksonville, North Carolina, and was accompanied by two documents, which demonstrated the legal acquisition of this piece. 
Table 2. Results of Analysis of the Legal Awareness and Provenance Quality of eBay Antiquities Dealers.

\begin{tabular}{|c|c|c|c|c|}
\hline Dealer No. & Location & Other Selling Platforms? & Legal Awareness Demonstrated? & Provenance Quality \\
\hline eD. $1^{1}$ & United Kingdom & No & $\begin{array}{c}\text { Yes } \\
\text { Awareness of UK Export laws. }\end{array}$ & $\begin{array}{c}\text { Average: } \\
\text { provenance certificate provided for lots with “known” provenance; } \\
\text { ownership history narratives; } \\
\text { significant representation of sales with no provenance data. } \\
\text { Average: }\end{array}$ \\
\hline eD.2 & Didcot, UK & No & No & $\begin{array}{c}\text { Provenience: Metal detecting finds from the UK; } \\
\text { ownership history narratives; } \\
\text { significant representation of sales with no provenance data. }\end{array}$ \\
\hline eD.3 & Luxor, Egypt & No & No & $\begin{array}{l}\text { Poor: } \\
\text { "NOTE" All items are rare Egyptian pieces extracted from the city of Luxor } \\
\text { and were purchased from the original owner." }\end{array}$ \\
\hline eD.4 & Serbia & No & No & $\begin{array}{l}\text { Poor: } \\
\text { no provenance data provided. }\end{array}$ \\
\hline eD.5 & Lviv, Ukraine & No & No & $\begin{array}{l}\text { Poor: } \\
\text { "In my shop sells only original items found in the territory of Ukraine". }\end{array}$ \\
\hline eD.6 & Montana, USA & No & No & $\begin{array}{l}\text { Average: } \\
\text { ownership history narratives. }\end{array}$ \\
\hline eD.7 & Graz, Austria & No & No & $\begin{array}{c}\text { Poor: } \\
\text { no provenance data provided. }\end{array}$ \\
\hline eD. 8 & Pireas, Greece & No & No & $\begin{array}{l}\text { Poor: } \\
\text { Roman silver rabbit figure: "personal find"- }\end{array}$ \\
\hline eD.9 & New York, USA & Advertises via Facebook & No & $\begin{array}{l}\text { Poor: } \\
\text { provides identical ownership history "Private US Collection" for all sales. } \\
\text { Average: }\end{array}$ \\
\hline eD.10 & Poland and Thailand & No & No & $\begin{array}{c}\text { dealer's personal collection; } \\
\text { ownership history narratives; } \\
\text { significant representation of sales with no provenance data. }\end{array}$ \\
\hline eD.11 & Cyprus & No & No & $\begin{array}{c}\text { Poor: } \\
\text { no provenance data provided. }\end{array}$ \\
\hline eD.12 & Israel & Advertises via Facebook & $\begin{array}{c}\text { Yes } \\
\text { "All my items come from a legal source". }\end{array}$ & $\begin{array}{l}\text { Poor: } \\
\text { personal collection: "I bought them on eBay". } \\
\text { High: }\end{array}$ \\
\hline eD.13 & USA & No & $\begin{array}{c}\text { Yes } \\
\text { "All antiquities are of legal provenance." }\end{array}$ & $\begin{array}{l}\text { High: } \\
\text { Cyprus limestone head sold with documents from the Cypriot Government c. } \\
1990 \text { s, attesting to their legality. }\end{array}$ \\
\hline eD.14 & Colchester, UK & $\begin{array}{l}\text { Has a website under a different name; } \\
\text { Advertises via Instagram and Twitter }\end{array}$ & No & $\begin{array}{c}\text { Average: } \\
\text { ownership history narratives; } \\
\text { significant representation of sales with no provenance data. } \\
\text { Average: }\end{array}$ \\
\hline eD.15 & East Sussex, UK & No & No & $\begin{array}{l}\text { ownership history narratives; } \\
\text { significant representation of sales with no provenance data; } \\
\text { "Property of a European Gentleman". }\end{array}$ \\
\hline
\end{tabular}

${ }^{1}$ eD: eBay dealer. 


\subsection{Social Media Dealers}

There were only two examples of legal engagement in the social media dealer category. The quality of provenance demonstrated was also low, with only one dealer identified with average-quality provenance narratives and rest of poor quality. Further, of these 14 dealers, eight made no attempt to provide provenance information to potential buyers. Four of the social media dealers advertised multiple selling platforms, two of which were brick-and-mortar businesses. Another was connected with a jewellery selling website. The final dealer used both eBay and Etsy as selling platforms. Etsy is an e-commerce site focused on handmade or vintage items and craft supplies and is modelled on traditional open craft fairs by providing sellers with personal storefronts for a small fee. Their seller policies include regulations concerning the sale of illegal items, acknowledging that legality shifts across different markets. However, apart from Native American crafts and remains, there is no specific mention of the trade of cultural heritage and the relevant legal frameworks.

The first of the two dealers who demonstrated legal awareness sells antiquities on Etsy, eBay and Instagram (SMD.4, Table 3). The Etsy account offered a legal testimony that references "all international and national laws and conventions" relevant to the sale of antiquities and cultural heritage. This is unsurprising considering that the dealer operates across so many selling platforms and has been dealing since 2009. However, similar to dealers in the other categories, this seller did not support this legal statement with high-quality provenance narratives. The second social media dealer who engaged with the legal framework was a New Jersey-based Facebook Marketplace user (SMD.10, Table 3). At the time of data collation, the dealer had four sales postings in the New York Facebook marketplace. One of these listings, a stone amulet offered for $\$ 540$, engaged with the legal framework through reference to export restrictions: "This Item Has Not Been Imported and is a UK Purchase". The exact wording in this listing bears a striking resemblance to one of the eBay dealers already discussed (eD.1, Table 2). A quick survey of their eBay seller feedback revealed eight sales in the past 12 months with the same listing title as SMD.10's post on the Facebook marketplace, implying that they had purchased the amulet from eD.1 and then offered it for sale once more at an inflated price, using the original item description. What this transaction demonstrates is not only the exchange of antiquities across selling platform but the transfer of values. Many of these internet dealers are likely not generating their own understandings of the legal framework but are adopting existing discourses when they purchase from other dealers.

Whilst many of the antiquities were sold without any provenance information, there was one sales listing in this group that stood out. Offered for sale on the London Facebook Marketplace, the piece was listed as a "Spiritual Egyptian antique face" and was offered for sale for $£ 5000$. The seller (SMD.15, Table 3) offered the following description for this piece: "Its been found during digging under 12 foot deep in ground and its heavy in weight cuz its made of stone great history piece." Whilst the authenticity of the latter piece is questionable, this does not detract from the insight that can be garnered from this sale and how sellers engage provenance narratives to demonstrate the authenticity of wares. This sale is akin to the cuneiform tablet, which was still covered in sand, and was framed to have been acquired under clandestine conditions. These types of descriptions are commonplace in the trade of illicit antiquities, reminiscent of authenticity photos that depict artefacts in the process of being illegally looted, and reinforce one of the depressing realities of the modern antiquities market: to collectors and dealers, the authenticity of an object is far more important than its legal status [27,28]. 
Table 3. Results of Analysis of the Legal Awareness and Provenance Quality of Social Media Antiquities Dealers.

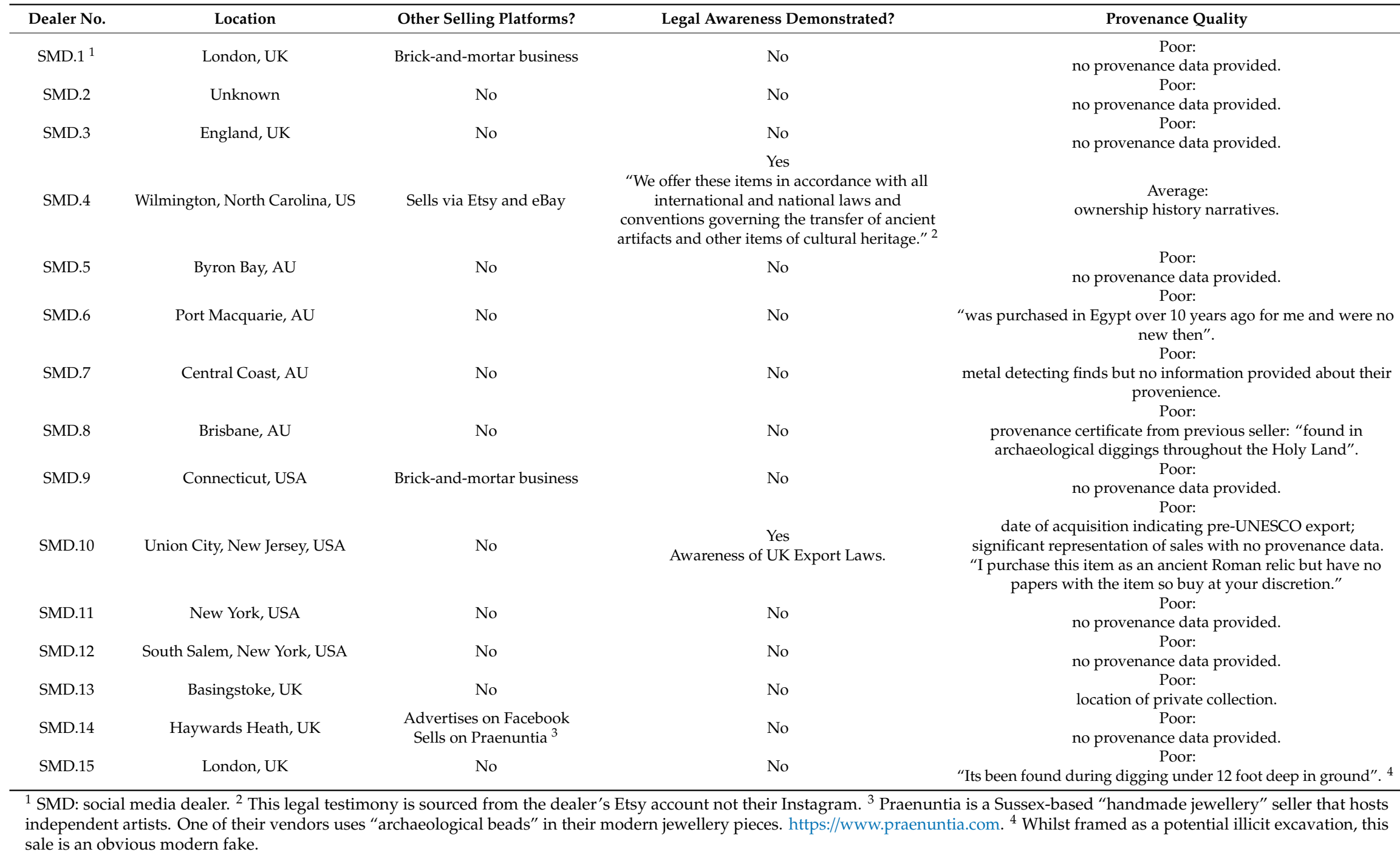




\subsection{Neutralisation Techniques}

Before moving to an overall discussion of these results, I would like to discuss a subset of the data within the framework of David Matza and Gresham Sykes' theory of neutralisation techniques [29]. In the 1950s, as part of their seminal work on delinquency, Matza and Sykes proposed that criminal behaviour is made possible by the theoretical strategies enacted by those who commit illegitimate or illegal acts, by which they can temporarily neutralise certain internal values, which normally would prohibit them from committing such an act. Within their framework, Matza and Sykes argued for five major types of neutralisation techniques, including the denial of responsibility; the denial of injury; the denial of the victim; condemnation of the condemners; and the appeal to higher loyalties. In 2016, Simon Mackenzie and Donna Yates produced a study that observed neutralisation techniques in the attitudes and practices of antiquities collectors [30]. These techniques are used to create a robust "social story that repels criticism and casts this type of collecting as a 'good thing'" [30] (p. 351). When examining this dataset of internet antiquities sales, these neutralisation techniques were evident in the opinions and values of three antiquities dealers: two based in the UK and one located in North Carolina.

The first example from one of the UK-based dealers (ID.5, Table 1) was a three-paragraph response to the question: "But isn't there a lot of looted material on the market?" Each paragraph reflected a different example of a neutralisation technique. The first was a condemnation of the condemners; in this case, "the vocal extremists of the archaeological community". This paragraph was fraught with tension, indicating a clear us versus them mentality, and the archaeological community was framed as being an elitist force that believes "only they should be able to handle ancient objects". There was also the further implication that the narratives about looting and trafficking that emanate from the archaeological community are fictions employed to ensure that they are the only guardians of the past. The second paragraph was longer and included examples of both the denial of responsibility and injury. To counter the claim that if an antiquity is unprovenanced, it is most likely looted, three embedded arguments were used to distance antiquities dealers from the crimes of looting and trafficking. In the final paragraph, there was an example of the neutralisation technique that Mackenzie and Yates deem to be the most crucial to the attitudes and beliefs of antiquities dealers: appeals to higher loyalties [30]. From this, not only are antiquities dealers and collectors removed from any criminal actions or behaviours, but they are actually "owed a debt of gratitude". Their contribution to museums, public collections and the preservation of our shared cultural heritage are framed as justifications for engaging in a market that is historically problematic, at best, and outright illegal at the worst.

The second example was from the other UK dealer's website (ID.7, Table 1) and was briefer but engaged with a similar rhetoric of neutralisation. Illegal digging, for example, was almost exclusively associated with the "upper end of the market", denying that any injury to the source countries and their heritage can be observed in the internet market for antiquities. There was also an appeal to higher loyalties, with a direct engagement with a collector-as-saviour narrative, framing collecting as a "force for preservation rather than destruction". Finally, there was an example of the denial of victimhood directed towards museums and research institutions. This idea that these institutions do not have the capacity to safeguard all antiquities is often used to also deny the victimhood of the source countries that have been systematically looted to supply the demand for antiquities in market countries.

The final dealer (SMD.4, Table 3) did not demonstrate the use of neutralisation techniques on the websites (Etsy and Instagram) where they presented antiquities for sale but, rather, did so on a blog hosted by Wordpress. In a series of four articles, published between 2015 and 2019, the dealer engaged with the issue of safeguarding antiquities from a pro-private collecting perspective. In their own words, these articles dealt with "issues surrounding the illicit trade in antiquities and some of the more inflated claims made by those in the cultural heritage industry". This framing is reminiscent of the language evident in the earlier example, where the dealer criticised the archaeological community for misrepresenting the facts of antiquities looting and trafficking. Unfortunately, these articles fall outside the scope of this paper, but a closer examination of this example of engagement with the legal framework and use of neutralisation techniques is intended for further study. 
However, these three dealers and their use of neutralisation techniques represent only a small portion of this investigated dataset of the internet antiquities market. This naturally promotes a new question to consider: why do some dealers use neutralisation techniques and others not? There were some commonalities between ID.5, ID. 7 and SMD.4, with all three dealers boasting lengthy careers in the antiquities market. ID.5 and SMD.4 both claimed to have been dealing in antiquities for more than 25 years, whereas ID.7 explained that their experience with the market stemmed from being a long-term private collector. Two of these dealers were also based in the UK, where the debate around regulated metal detecting and antiquities collecting has contributed to ongoing tensions between market participants and cultural heritage professionals [31]. As such, perhaps these two dealers have been well versed in these sorts of discussions and have therefore utilised neutralisation techniques more frequently in defence of their operations. Further, these three examples of neutralisation techniques were found on internet platforms where there is a less structured format provided by host websites, such as eBay or Etsy. When designing an independent website, or a Wordpress blog, dealers have more agency over the size and scope of their content, which could possibly contribute to these lengthier engagements with the legal framework.

These conclusions, however, do not account for the dealers in this study who have been in the business as long as ID.5, ID.7 and SMD.4 or the large number of dealer who operate in the UK, or even the $15+$ dealers who operate using their own independent websites. Unfortunately, it is not clear from the current data why some dealers do utilise neutralisation techniques and why others do not, which makes this an ideal area for further research.

\section{Discussion}

These results from this analysis of 45 internet antiquities dealers must now be considered against the four hypotheses. Starting with the first hypothesis, internet dealers did indeed demonstrate the highest level of engagement with the legal framework when compared with the eBay and social media dealers. Further, awareness of their legal obligations was demonstrated by these dealers in a number of ways, including references to specific international treaties, bilateral agreements, and export laws and restrictions. However, the positivity of these results is somewhat undermined by the examples of dealers attempting to neutralise and deflect their legal obligations. The impact of the use of these neutralisation techniques, and in particular, the dissemination of the collector-as-saviour narrative, cannot be understated in the context of the internet market for antiquities. Such narratives and beliefs are incongruous with the reality of the modern antiquities market, shaped by systematic looting, trafficking and other criminal acts.

Moving now to the second hypothesis, the eBay dealers demonstrated a much lower level of engagement with the legal framework than expected. Admittedly, these results could have been caused the limited sample size. A larger sample size would likely better correspond with this statement and show the expected level of variation and diversity. That being said, 10 of the 15 dealers had been active on eBay for more than five years, suggesting they had at least some experience with the market.

The third hypothesis was found to be accurate and the level of engagement with the legal framework was fairly consistent across the eBay and social media dealers. With only five dealers across these two categories demonstrating legal awareness, it is safe to say that engagement with the complex cultural heritage legal framework is generally poorer than what can be observed in the businesses of more established internet antiquities dealers. Further, not only were there few dealers engaging with the legal framework, but the ways in which the eBay and social media dealers did demonstrate legal awareness were quite limited.

Finally, a high engagement with the legal framework did not always translate to a demonstration of ethical behaviours and practices. The dealer who cited MoUs and international heritage conventions at length did not necessarily provide examples of antiquities with higher provenance. These results challenge us to think of legal obligations in a different way-not as a tool that operates as checks and balances of behaviour but, rather, as an act of branding, a performance of values and ethics to support 
the dealer's reputation in the market. Low engagement, however, did more frequently correspond with poorly provenanced antiquities. This was especially the case with the social media dealers, who offered the highest number of antiquities with withheld provenance and the lowest engagement with the legal framework overall.

\section{Conclusions}

In his policy brief for the Antiquities Coalition, Neil Brodie argued that in the internet market for antiquities self-regulation appears to be largely non-existent [9]. The results of this study clearly support this argument: whilst the legal framework of the trade of cultural heritage was engaged with by some dealers of the internet market for antiquities, the level of legal literacy was depicted as being quite poor. Whether this is the reality is another question altogether, as it is entirely possible that some dealers know more about their legal obligations than they express on their websites, eBay profiles and social media pages. What is clear, however, is that even when dealers do demonstrate a strong engagement with the legal framework, this does not necessarily correspond with ethical dealer practices and behaviours.

Historically, the standards for provenance in the antiquities trade are very low and have resulted in a global market where the "licit" cannot easily be separated from the "illicit". The realities of this practice have placed heightened pressure on dealers and collectors to perform due diligence and ensure that the antiquities that they have acquired have not come to their possession through illegal means. However, in the case of these internet dealers, high engagement with a legal framework is often undermined by the sale of poorly provenanced antiquities. This widespread and normalised practice is a dangerous one as it reinforces unethical market values. Further harm appears in the use of neutralisation techniques by some internet antiquities dealers. Whilst not common within this dataset, this practice is still concerning as these narratives are used to reinforce unethical, and even criminal, practices and behaviours that have long obstructed attempts to regulate the illicit trade of antiquities. The popular collector-as-saviour narrative is particularly harmful, if we consider the presence of new collectors who have only accessed the antiquities market via the internet.

However, it is these new market participants who provide an ideal audience for educational campaigns targeted at raising consumer awareness by challenging these misleading narratives and highlighting the ethical issues involved with the trade of cultural heritage. Whilst this undertaking must involve the efforts of academics, NGOs, cultural heritage professionals, policing agencies and the dealers themselves, the role of the sales-hosting platforms, such as eBay, Facebook and Instagram, cannot be ignored either. Of course, raising consumer awareness can only do so much in regulating the internet market for antiquities. This approach must be supported by the development and implementation of systematic regulation and monitoring policies-ones which allow for successful criminal prosecutions when internet dealers do trade in illicit antiquities. Education has crucial a role to play, however, in changing the ethics of the market, and improving legal awareness is just one part of a much larger and more complicated undertaking.

Funding: This research received no external funding.

Acknowledgments: This paper was originally presented at Investigating and Policing Antiquities Trafficking and Forgery in a Digital Age, Stockholm University (25-26 April 2019). I would like to acknowledge the assistance of Associate Professor Malcolm Choat, Rachel Yuen-Collingridge and Damien Huffer in the development of this paper, as well as James Donaldson (RD Milns Antiquities Museum, University of Queensland) for introducing me to the existence of antiquities in the Facebook Marketplace. I would also like to acknowledge the traditional owners of the land on which I have researched and written this paper: the Wattamattagal clan of the Darug Nation and the Cammeraygal people of the Eora Nation. I extend my respect to Elders, past, present, and future; to their relationship with the land and to their cultural heritage - the theft, appropriation and destruction of which inspired me to conduct research into the illicit antiquities trade.

Conflicts of Interest: The author declares no conflict of interest. 


\section{References and Note}

1. This eBay seller came to my attention via an email containing a link to a papyrus sale, sent from Assoc. Prof. Choat, who learnt of it from Dr Alin Suicui. Choat and the Forging Antiquity team (www.forgingantiquity. com) believe the papyrus in this eBay sale to be modern forgeries.

2. Brodie, N. The Market in Iraqi Antiquities 1980-2009 and Academic Involvement in the Marketing Process. In Crime in the Art and Antiquities World: Illegal Trafficking in Cultural Property; Manacorda, S., Chappell, D., Eds.; Springer: New York, NY, USA, 2011; pp. 117-131.

3. United States Department of Justice. Press Release. Available online: https://www.justice.gov/usao-edny/ press-release/file/978096/ (accessed on 18 July 2019).

4. Moss, C.R.; Baden, J.S. Bible Nation: The United States of Hobby Lobby; Princeton University Press: Princeton, NJ, USA; New York, NY, USA, 2017.

5. Hicks-Keeton, J.; Concannon, C. (Eds.) The Museum of the Bible: A Critical Introduction; Fortress Academic: Lanham, MA, USA, 2019.

6. Campbell, P.B. The Illicit Antiquities Trade as a Transnational Criminal Network: Characterizing and Anticipating Trafficking of Cultural Heritage. Int. J. Cult. Prop. 2013, 3, 113-153. [CrossRef]

7. Mackenzie, S. Organised Crime \& Common Transit Networks. In Trends $\mathcal{E}$ Issues in Criminal Justice; Australian Institute of Criminology: Canberra, Australia, 2013.

8. Mackenzie, S. The Market as Criminal and Criminals in the Market: Reducing Opportunities for Organised Crime in the International Antiquities Market. In Crime in the Art and Antiquities World: Illegal Trafficking in Cultural Property; Manacorda, S., Chappell, D., Eds.; Springer: New York, NY, USA, 2011; pp. 69-85.

9. Proulx, B.B. Organized Criminal Involvement in the Illicit Antiquities Trade. Trends Organ. Crime 2011, 14, 1-29. [CrossRef]

10. Brodie, N. The Internet Market in Precolumbian Antiquities. In Cultural Property Crime: An Overview and Analysis on Contemporary and Trends; Kila, J., Balcells, M., Eds.; Brill: Leiden, The Netherlands, 2014; pp. 237-262.

11. Brodie, N. The Internet Market in Antiquities. In Countering Illicit Traffic in Cultural Goods: The Global Challenge of Protecting the World's Heritage; Demarais, F., Ed.; ICOM: Paris, France, 2015; pp. 11-20.

12. Brodie, N. Virtually Gone! The Internet Market in Antiquities. In Proceedings of the 6th International Conference of Experts on the Return of Cultural Property; Overseas Korean Cultural Heritage Foundation: Seoul, Korea, 2017; pp. 190-204.

13. Campbell, P.B. The Illicit Antiquities Trade as a Transnational Criminal Network. Int. J. Cult. Prop. 2013, 20, 130-131. [CrossRef]

14. Chippindale, C.; Gill, D. On-Line Auctions: A New Venue for the Antiquities Market. Cult. Context 2001, 9 , 2-13.

15. Fay, E. Virtual Artifacts: Ebay, Antiquities, and Authenticity. J. Contemp. Crim. Justice 2011, 27, 449-464. [CrossRef]

16. Lidington, $\mathrm{H}$. The Role of the Internet in Removing the 'shackles of the Saleroom': Anytime, Anyplace, Anything, Anywhere. Public Archaeol. 2002, 2, 67-84. [CrossRef]

17. Al-Azam, A.; Paul, K.A. How Facebook Made It Easier Than Ever to Traffic Middle Eastern Antiquities. World Politics Review. 2018. Available online: https://www.worldpoliticsreview.com/articles/25532/howfacebook-made-it-easier-than-ever-to-traffic-middle-eastern-antiquities (accessed on 19 July 2019).

18. UNESCO. Basic Actions Concerning Cultural Objects Being Offered for Sale over the Internet. 2016. Available online: http://www.unesco.org/new/fileadmin/MULTIMEDIA/HQ/CLT/pdf/basic-actions-cultural-objectsfor-sale_en.pdf (accessed on 19 July 2019).

19. Brodie, N. How to Control the Internet Market in Antiquities? The Need for Regulation and Monitoring? The Need for Regulation and Monitoring. Antiquities Coalition Policy Brief No. 3. 2017. Available online: http://thinktank.theantiquitiescoalition.org/wp-content/uploads/2017/07/Policy-Brief-3-2017-07-20. pdf (accessed on 19 July 2019).

20. Kersel, M. Walking a Fine Line: Obtaining Sensitive Information Using a Valid Methodology. In Heritage Studies: Methods and Approaches; Stig Sørenson, M.L., Carman, J., Eds.; Routledge: London, UK, 2010; pp. 178-200. 
21. Krombholz, K.; Merkl, D.; Weippl, E. Fake identities in social media: A case study on the sustainability of the Facebook business model. J. Serv. Res. 2012, 4, 175-212. [CrossRef]

22. White, J.B. The Invisible Discourse of the Law: Reflections on Legal Literacy and General Education. Univ. Colo Law Rev. 1983, 54, 143-159.

23. Blake, J. International Cultural Heritage Law; Oxford University Press: Oxford, UK, 2015.

24. Forrest, C. International Law and the Protection of Cultural Heritage; Routledge: London, UK, 2011.

25. Lixinksi, L. International Heritage Law for Communities-Exclusion and Re-Imagination; Oxford University Press: Oxford, UK, 2019.

26. Lyman, R.L. A Historical Sketch on the Concepts of Archaeological Association, Context, and Provenience. J. Archaeol. Method Theory 2012, 19, 207-240. [CrossRef]

27. Yates, D. Value and doubt: The persuasive power of "authenticity" in the antiquities market. PARSE 2015, 2, 71-84.

28. Watson, P.; Todeschini, C. The Medici Conspiracy; Public Affaircs: New York, NY, USA, 2006.

29. Sykes, G.M.; Matza, D. Techniques of Neutralization: A Theory of Deliquency. Am. Sociol. Rev. 1957, 22, 664-670. [CrossRef]

30. Mackenzie, S.; Yates, D. Collectors on Illicit Collecting: Higher Loyalties and Other Techniques of Neutralization in the Unlawful Collecting of Rare and Precious Orchids and Antiquities. Theory Criminol. 2016, 20, 340-357. [CrossRef] [PubMed]

31. Barford, P. Portable Antiquity Collecting and Heritage Issues. Available online: http://paul-barford.blogspot. com (accessed on 19 July 2019).

(C) 2019 by the author. Licensee MDPI, Basel, Switzerland. This article is an open access article distributed under the terms and conditions of the Creative Commons Attribution (CC BY) license (http://creativecommons.org/licenses/by/4.0/). 